\title{
Organellar genome copy number variations and integrity across different organs, growth stages, phenotypes and main localities of sago palm (Metroxylon sagu Rottboll) in Sarawak, Malaysia
}

\author{
Leonard Whye Kit Lim ${ }^{\mathrm{a}, *}$, Hung Hui Chung ${ }^{\mathrm{a}, *}$, Hasnain Hussain ${ }^{\mathrm{b}}$ \\ ${ }^{a}$ Animal Biotechnology Lab II, Faculty of Resource Science and Technology, Universiti Malaysia Sarawak, 94300 Kota Samarahan, Sarawak, Malaysia \\ ${ }^{\mathrm{b}}$ Centre for Sago Research (CoSAR), Faculty of Resource Science and Technology, Universiti Malaysia Sarawak, 94300 Kota Samarahan, Sarawak, Malaysia
}

\section{A R T I C L E I N F O}

\section{Keywords:}

Metroxylon sagu Rottboll

Food crop

Mitogenome

Plastome

Non-trunking

Spiny

\begin{abstract}
A B S T R A C T
The sago palm (Metroxylon sagu Rottboll) is one valuable food crop that has both high economic and nature value with promising potential to curb future global hunger issues. The organellar genomes, namely mitogenome and plastome, are indispensable in various development processes of plants, orchestrating the survivability and adaptability of the host and fulfilling its physiological needs. The long-PCR and qPCR approaches were used in couple to reveal the organellar genome copy number variations across different organs, growth stages, phenotypes and main localities in Sarawak, Malaysia. In this study, the mature leaf achieved among the highest unimpeded plastome and mitogenome copy number among other organs such as young root, mature root, young shoot, aged leaf and pneumatophore. The Plawei Manit stage scored the highest in terms of unimpeded mitogenome and plastome copy number across other four growth stages. The non-trunking and spiny phenotypes inspected have lower organellar genome copy numbers than the trunking phenotype. All three phenotypes sampled from four different localities in Sarawak, Malaysia showed no significant difference. This study serves as a steppingstone in unravelling the organellar genome copy number variations of sago palm and this knowledge is essential for future genotyping studies.
\end{abstract}

\section{Introduction}

Metroxylon sagu Rottboll is one true palm categorized under the Calamoideae subfamily, Palmae family and Arecales order. The term sago came from the indigenous naming of the starch and its derivatives from this palm tree where it is widely propagated (Dransfield, 1976; Johnson, 1976; Ruddle, 1976; Kiew, 1976). This palm tree was the staple starch source and essential trade article in the Malay Achipelago region of Southeast Asia prior to the rise of the paddy/rice agriculture (Tan, 1983). Now, it can be found abundantly across Southeast Asia regions encompassing Thailand, Vietnam, Malaysia and the Philippines apart from Oceania regions like Oceanian Islands and Papua New Guinea, as well as Bangladesh (Johnson, 1976). In Malaysia, the largest sago producer state is none other than the Sarawak state covering areas like Pusa, Mukah, Saratok, Balingan and Oya-Dalat (Chew et al., 1999) but albeit the plantation area involved is only $<1 \%$ of total agricultural land use in Malaysia, the Sarawak state is the world's largest exporter giant of sago amounting to 42,000 t per annum in 2017 to countries like
Singapore, Japan, Peninsular Malaysia and Taiwan (Sarawak State Secretary Office, 2020).

Beside its capability to grow up to the height of $15 \mathrm{~m}$ and on elevation of up to $1000 \mathrm{~m}$, this semi-wild palm species is well-known for its hardy characteristics of surviving well in high salinity and acidic soils with high levels of metals such as manganese, aluminum and iron (Bintoro et al., 2018). It takes a decade to a decade and a half for it to flower once per lifetime before bearing fruit and completes its entire lifecycle consisting of five growth stages: Plawei, Plawei Manit, Bubul, Angau Muda and Angau Tua (Lim, 1991); its trunk is filled with the maximum amount of starch right before the flowering commences. The sago palm is an underappreciated food crop as it bears the solution to strengthen future global food security issues due to its numerous contributions to a myriad of industries (as reviewed by Lim et al., 2019) as well as beneficial to the environment as its carbon dioxide absorption capability is the highest among other major crops (Bintoro et al., 2018). On the side note, its tolerance to harsh growing environments (Hussain et al., 2020; Lim and Chung, 2020) added with its highest starch yield

\footnotetext{
Abbreviations: DNA, deoxyribonucleic acid; PCR, Polymerase Chain Reaction

* Corresponding authors.

E-mail addresses: 19010029@siswa.unimas.my (L.W.K. Lim), hhchung@unimas.my (H.H. Chung).
} 